\title{
THYROXINE BINDING CAPACITY OF SERUM ALPHA GLOBULIN IN HYPOTHYROID, EUTHYROID, AND HYPERTHYROID SUBJECTS ${ }^{1}$
}

\author{
BY EDWIN C. ALBRIGHT, FRANK C. LARSON, AND WILLIAM P. DEISS
}

\begin{abstract}
(From the Department of Medicine, University of Wisconsin Medical School, and Veterans Administration Hospital, Madison, Wis.)
\end{abstract}

(Submitted for publication August 6, 1954; accepted September 13, 1954)

Circulating thyroxine is associated with a specific serum alpha globulin $(1-6)$. This thyroxinebinding globulin (TBG) appears to exist in plasma in quantity greater than is required to bind endogenous thyroxine, for it will bind additional thyroxine when added in vitro (6-8). This capacity of TBG to bind exogenous thyroxine in vitro appeared in preliminary studies (9) to depend upon the state of thyroid gland activity. The purpose of this paper is to report in more detail the capacity of the serum of hypothyroid, euthyroid, and hyperthyroid subjects to bind added thyroxine.

\section{MATERIALS AND METHODS}

All subjects studied were seen in the Department of Medicine of the University of Wisconsin. The subjects were either hypothyroid (nine), euthyroid (nine), or hyperthyroid (nineteen), as judged by symptoms, physical findings, 24-hour $\mathrm{I}^{212}$ uptake and other appropriate measurements. Two of the hypothyroid subjects were athyreotic following total thyroidectomy.

Ten micrograms of $I^{121}$ labelled thyroxine ${ }^{2}$ in propylene glycol were added to one milliliter of a solution containing 90 micrograms per milliliter of inert thyroxine. The latter solution was prepared from chromatographically purified thyroxine which had been quantitated gravimetrically. This procedure was adopted to minimize possible error in the quantitation of the labelled thyroxine. This mixture was then diluted to $10 \mathrm{ml}$. Appropriate aliquots of this solution were added to serum to yield a series of dilutions containing 0.01 to 1.0 micrograms per milliliter.

Fifty microliters of each of these mixtures were submitted to paper zone electrophoresis as previously described (3). On completion of the electrophoresis, the paper strips were dried and the radioactivity determined by use of a chromatogram scanner. The distribution of radiothyroxine was obtained by computing with a planimeter the area under the curves produced by the re-

\footnotetext{
1 This work was supported in part by the Wisconsin Alumni Research Foundation.

2 Obtained from Abbott Laboratories, Oak Ridge, Tennessee. (Preparations not at least 95 per cent pure were repurified by paper chromatography.)
}

cording galvanometer of the scanner. ${ }^{3}$ The amount of thyroxine bound by the TBG was estimated as follows:

TBG-bound thyroxine $=\frac{\text { Area TBG }}{\text { Total area }} \times$ thyroxine added

\section{RESULTS}

In all sera examined the thyroxine appeared in the alpha globulin zone. At the lowest concentrations used ( 0.01 to 0.05 micrograms per milliliter) only a very small amount of thyroxine appeared in the albumin. As the concentration of thyroxine was increased from 0.1 to 1.0 micrograms per milliliter, a greater proportion of thyroxine appeared in the albumin as the alpha globulin binding capacity appeared to become relatively saturated. In Figure 1 are shown representative curves of distribution of radiothyroxine following electrophoresis of sera from euthyroid, hypothyroid, and hyperthyroid subjects. It is evident that there is a greater accumulation of radiothyroxine in the TBG of the hypothyroid subject and conversely less in the hyperthyroid.

Figure 2 is a scattergram showing the relation between the quantity of radiothyroxine added to serum and that bound by the TBG. In the lower concentrations ( 0.05 to 0.4 micrograms per milliliter) this relationship is roughly linear. At higher concentrations ( 0.4 to 1.0 micrograms per milliliter) relatively less of the added radiothyroxine appears in the TBG. A plateau is thereby produced, which is believed to reflect a "saturation" of the TBG. The concentration at which "saturation" occurs varies with the state of thyroid activity; being approximately 0.15 to $0.2 \mathrm{mi}$ crograms radiothyroxine per milliliter in the hy-

8 By adding varying quantities of radiothyroxine in spots along a paper strip it was possible to demonstrate a linear relationship between the amount of radioactivity and the area under the curve regardless of the geometry of the spot. 


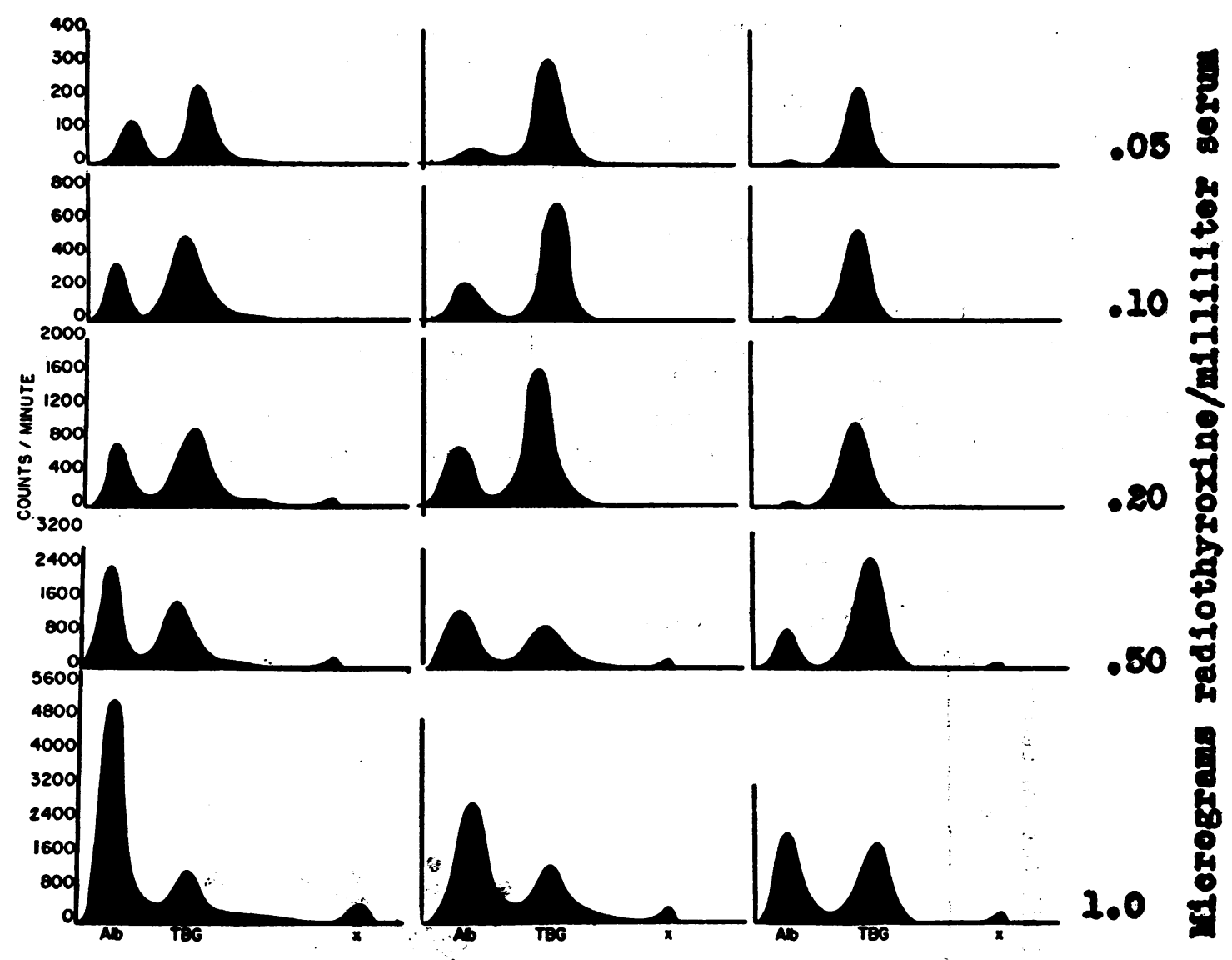

$\Delta$

B

C

Fig. 1. Distribution of Radiothyroxine Following Electrophoresis of Sera frox (A) Hyperthyroid, (B) EUthyroId; AND (C) HYPOTHYroId

$x$-indicates starting point of electrophoresis

TBG-indicates thyroxine binding globulin

$\mathrm{Alb}$-indicates albumin

As the radioactivity of the preparations increased, narrower slit-openings were used in the scanner, hence there is no absolute relationship of the radioactivity from one concentration to the next.

perthyroid, 0.25 micrograms per milliliter in the euthyroid, and 0.4 to 0.5 micrograms per milliliter in the hypothyroid.

\section{DISCUSSION}

The capacity of TBG to bind thyroxine is relatively specific. Triiodothyronine also associates with this protein but it can be displaced readily with thyroxine while the converse is not so (7). The presence of large quantities (10 times molar concentration of thyroxine) of tyrosine, diiodotyrosine, diiodothyronine and iodide ion fails to interfere with the TBG thyroxine binding (10). This specific binding in the normal is observed only when the quantity of added thyroxine is less than 0.1 micrograms per milliliter. When the concentration exceeds this level, the thyroxine can be found in all protein fractions with albumin the main secondary carrier.

The radiothyroxine added in vitro appears to exchange freely with the thyroxine previously bound. This can be demonstrated by adding 0.1 microgram radiothyroxine to one milliliter of normal serum, allowing 20 minutes of incubation 
at 37 degrees $\mathrm{C}$, and then adding one microgram of thyroxine. Under these circumstances 40 per cent of the radioactivity appears in the TBG and 60 per cent in the albumin. The same distribution of radioactivity is observed when the two additions are made in reverse order.

The present data confirm the earlier report that the in vitro binding capacity of TBG for added thyroxine depends upon the state of thyroid function (9). The relationship is inverse, the hypothyroid binding more and the hyperthyroid less thyroxine than normal. This is assumed to indicate that this protein in hyperthyroid subjects is relatively saturated with endogenous thyroxine and conversely, relatively unsaturated in the hypothyroid. The occurrence of TBG in serum appears to be independent of thyroid gland function, as is shown by its presence in athyreotic subjects. Furthermore, the latter observation would indicate that TBG has an extra thyroidal origin.

If it be assumed that in the untreated athyreotic individual the TBG is completely free of thyroxine and is present in normal quantities, it appears that it is able to bind approximately 0.4 to 0.5 micrograms of thyroxine per milliliter of serum. If the

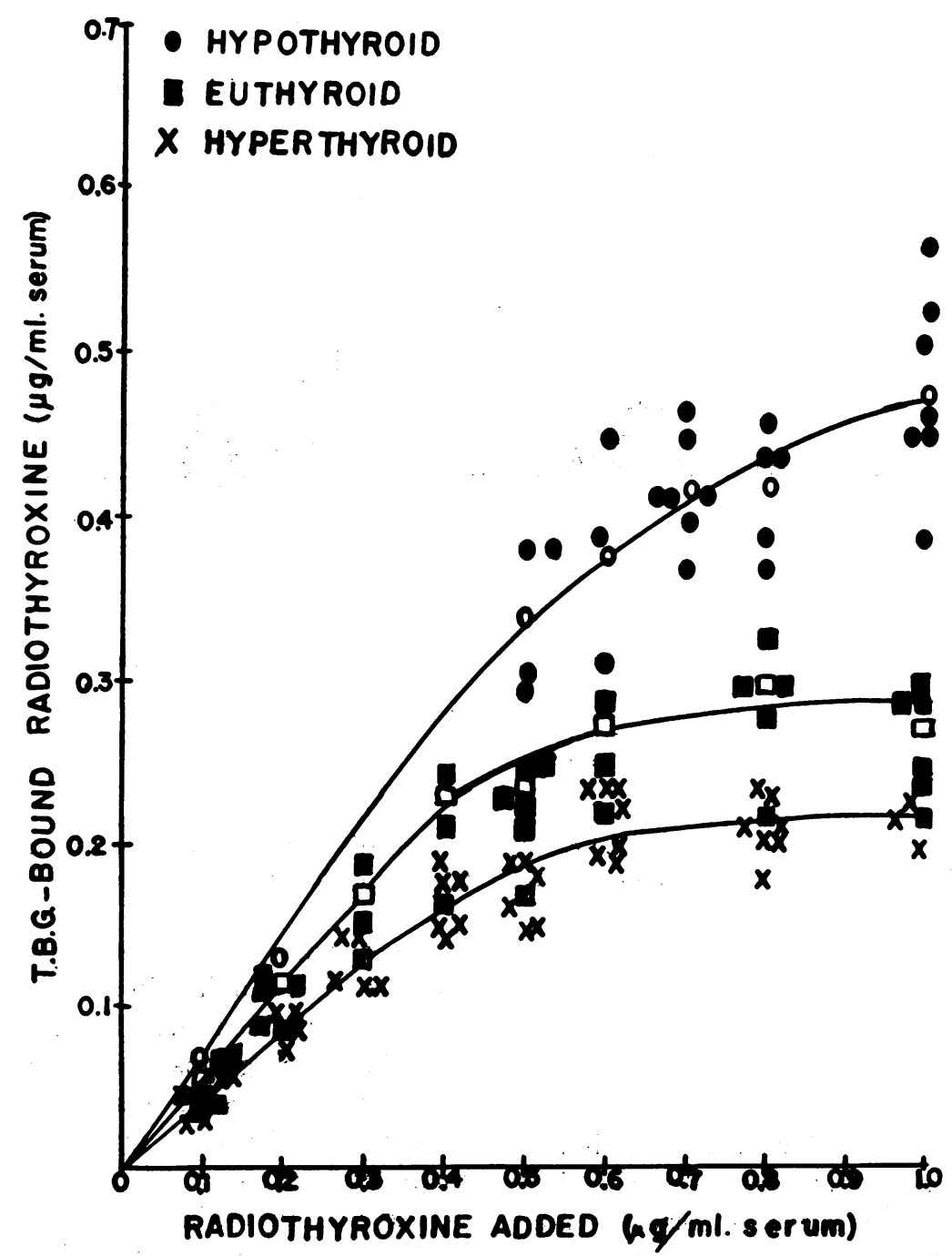

Fig. 2. Graph Showing Relation Betwern Quantity of Radiothyroxine AdDed to SERUM aNd that Bound by the ThyroxineBinding-Globulin (TBG)

Open symbols indicate the mean. 
plasma concentrations of endogenous thyroxine calculated from PBI determinations are taken as 0.00 to 0.05 micrograms per milliliter for the hypothyroid, 0.10 to 0.15 micrograms per milliliter for the euthyroid, and 0.2 to 0.25 micrograms per milliliter for the hyperthyroid, it can be seen that the sum of this endogenous thyroxine and the added exogenous thyroxine as estimated from the present data, is in each category approximately 0.4 to 0.5 micrograms per milliliter. This suggests that there may be little variation in the concentration of TBG from one individual to another regardless of the state of thyroid activity. Thus, in the normal subject endogenous thyroxine occupies only one-third of the TBG binding capacity, while in the hyperthyroid one-half or more of this capacity is utilized.

\section{SUMMARY}

1. Thyroxine labelled with $\mathrm{I}^{181}$ was mixed with the sera of patients with varying thyroid function, and these mixtures were subjected to paper electrophoresis. The concentration of radiothyroxine in the thyroxine binding globulin (TBG) was determined.

2. The amount of added thyroxine bound by the TBG varies inversely with thyroid function. This is assumed to indicate that this protein is relatively saturated with endogenous thyroxine in the hyperthyroid and relatively unsaturated in the hypothyroid.

3. From evidence in an athyreotic individual it appears that the total thyroxine binding capacity of the TBG is 0.4 micrograms per milliliter, only one-third of which is utilized in the normal subject.

\section{ACKNOWLEDGMENT}

The authors wish to acknowledge the invaluable assistance of Miss Sue Ames, Medical Technician.

\section{REFERENCES}

1. Larson, F. C., Deiss, W. P., and Albright, E. C., Localization of protein-bound radioactive iodine by filter paper electrophoresis. Science, 1952, 115, 626.

2. Gordon, A. H., Gross, J., O'Connor, D., and PittRivers, R., Nature of the circulating thyroid hormone-plasma protein complex. Nature, 1952, 169, 19.

3. Deiss, W. P., Albright, E. C., and Larson, F. C., A study of the nature of the circulating thyroid hormone in euthyroid and hyperthyroid subjects by use of paper electrophoresis. J. Clin. Invest., 1952, 31, 1000.

4. Winzler, R. J., and Notrica, S. R., Association of thyroxine with plasma proteins. Federation Proc., 1952, 11; 312.

5. Horst, W., and Rösler, H., Der transport des hormonjods in menschlichen serum untersucht mit papierelektrophorese und radiojod. Zugleich ein beitrag zur frage der existenz von sog. Zwischenfraktionen. Klin. Wchnschr., 1953, 31, 13.

6. Larson, F. C., Deiss, W. P., and Albright, E. C., Radiochromatographic identification of thyroxine in an alpha globulin fraction of serum separated by starch zone electrophoresis. J. Clin. Invest., 1954, 33, 230.

7. Deiss, W. P., Albright, E. C., and Larson, F. C., Comparison of in vitro serum protein binding of thyroxine and triiodothyronine. Proc. Soc. Exper. Biol. \& Med., 1953, 84, 513.

8. Robbins, J., Rall, J. E., and Petermann, M. L., Protein-binding of thyroxine in normal and nephrotic serum. J. Clin. Invest., 1954, 33, 959.

9. Albright, E. C., Larson, F. C., and Deiss, W. P., Observations on the capacity of serum alpha globulin to bind thyroxine in vitro. J. Clin. Invest., 1954, 33, 914.

10. Albright, E. C., Larson, F. C., and Deiss, W. P., Unpublished observations. 